Svay 



\section{May Mayko Ebihara}

\section{Svay}

\section{A Khmer Village in Cambodia}

\section{Edited by Andrew Mertha}

With an introduction by Judy Ledgerwood

\section{Southeast Asia Program Publications} an imprint of

Cornell University Press

Ithaca and London 
Southeast Asia Program Publications Editorial Board

Mahinder Kingra (ex officio)

Thak Chaloemtiarana

Chiara Formichi

Tamara Loos

Kaja McGowan

Andrew Mertha

"Svay: A Khmer Village in Cambodia" copyright (c) 1968 by May Mayko Ebihara

Preface and introduction copyright (c) 2018 by Cornell University

"Memories of the Pol Pot Era in a Cambodian Village" copyright (C) 2002 by the Center for Southeast Asian Studies, Northern Illinois University

All rights reserved. Except for brief quotations in a review, this book, or parts thereof, must not be reproduced in any form without permission in writing from the publisher. For information, address Cornell University Press, Sage House, 512 East State Street, Ithaca, New York 14850.

First published 2018 by Cornell University Press

Printed in the United States of America

Library of Congress Cataloging-in-Publication Data

Names: Ebihara, May, author. | Mertha, Andrew, 1965- editor.

Title: Svay : a Khmer village in Cambodia / May Mayko Ebihara ; edited by

Andrew Mertha ; with an introduction by Judy Ledgerwood.

Description: Ithaca, New York : Southeast Asia Program Publications, 2018. |

Originally presented as author's thesis (Ph.D)—Columbia University, 1971. |

Includes bibliographical references and index.

Identifiers: LCCN 2017020651 (print) | LCCN 2017044735 (ebook) |

ISBN 9781501714801 (pdf) | ISBN 9781501714719 (epub/mobi) |

ISBN 9781501715112 (hardback) | ISBN 9781501715129 (paper)

Subjects: LCSH: Khmers—Cambodia—Svay Riěng. | Village communities-

Cambodia-Svay Riĕng. | Svay Riĕng (Cambodia)—Social life and customs. |

Svay Riĕng (Cambodia)—History-20th century.

Classification: LCC GN635.C3 (ebook) | LCC GN635.C3 E25 2018 (print) |

DDC 959.604-dc23

LC record available at https://lccn.loc.gov/2017020651

Cornell University Press strives to use environmentally responsible suppliers and materials to the fullest extent possible in the publishing of its books. Such materials include vegetable-based, low-VOC inks and acid-free papers that are recycled, totally chlorine-free, or partly composed of nonwood fibers. For further information, visit our website at cornellpress.cornell.edu.

Cover illustration: May Mayko Ebihara, Transplanting, The May Ebihara Collection, Southeast Asia Digital Library, Northern Illinois University Libraries. Date accessed:10/5/2017, http://sea.lib.niu.edu. 